\title{
CROSS-CORRELATION OF COLOR AND ACIDITY OF WET BEECH WOOD IN THE PROCESS OF THERMAL TREATMENT WITH SATURATED STEAM
}

\author{
Ladislav Dzurenda, Michal Dudiak \\ Technical University in Zvolen \\ Slovakia \\ (Received June 2020)
}

\begin{abstract}
The paper presents changes in the color and acidity of Fagus sylvatica L. in the process of heat treatment of wood with saturated water steam in the temperature range $t=105-135^{\circ} \mathrm{C}$ during $\tau=3$ to 12 hours. The light white-gray color of beech wood with a yellow tint changes on the pale pink, red-brown to a brown-red color in the heat treatment process. The color changes of beech wood expressed in the form of the total color difference are in the range of values $\Delta E^{*}=1.97-26.85$. Due to the hydrolysis of hemicelluloses, the acidity changes in the process of thermal treatment of wet beech wood. Decrease in acidity of beech wood in the range of temperatures $t=105-135^{\circ} \mathrm{C}$ and time $\tau=3-12$ hours is in the range of $\mathrm{pH}$ values $=4.9$ to 3.4. The dependence of the total color difference $\Delta E^{*}$ on the change in acidity of beech wood is described by the polynomial of function II. degree. The above knowledge is a suitable tool for evaluating the degree of change in beech wood color in the technological process based on the change in $\mathrm{pH}$ of wood.
\end{abstract}

KEYWORDS: Wood, Fagus sylvatica L, acidity, color difference, thermal treatment, saturated water steam.

\section{INTRODUCTION}

Wood placed in the environment of hot water, saturated water steam or saturated humid air is heated and its physical, mechanical as well as chemical properties change. Thermal treatment of wood, besides physical and mechanical changes applied in the process of manufacturing veneers, plywood, bentwood furniture or pressed wood are accompanied with the changes in chemical properties and color of wood (Kollmann and Cote 1968, Sergovskij and Rasev 1987, Trebula 1986, Tolvaj et al. 2010, Dzurenda and Orlowski 2011, Dzurenda 2013, Baranski et al. 2017, Sikora et al. 2018). In the past, color changes when wood becoming darker during the steaming 
process were used to remove the undesirable color differences between light colored sapwood and dark colored heartwood or to eliminate wood stain colors as a result of mould. In recent times, research into thermally modified wood has been focused on the issue of the color change of specific wood species into more or less bright hues or wood imitation of domestic or exotic tree species (Molnar and Tolvaj 2002, Tolvaj et al. 2009, Dzurenda 2014, 2018a,b,c, Barcik et al. 2015, Baranski et al. 2017).

Free water in the lumens of wood cells is a dilute aqueous solution of sugars, organic acids and salts of calcium, magnesium, potassium, sodium, which are transported by the root system to the living tree (Čudinov 1968, Blažej et al. 1975, Zevenhoven 2001, Pňakovič and Dzurenda 2015). The value of the acidity of the aqueous solution in deciduous wood, in the range of $\mathrm{pH}$ values 5.5 - 4.8 (Sandermann and Rothkamm 1956, Solár 2014, Geffert et al. 2019).

The effect of thermal on wet wood is also initiated by chemical changes in wood. The first chemical reactions include partial hydrolysis of hemicelluloses and extraction of water-soluble substances (Fengel and Wegener 1984, Bučko 1995, Solár 2004, Sundqvist et al. 2006, Samešová et al. 2018). Depending on the temperature and duration of action of the hydrolysis products, which are acetic acid and formic acid, degradation of polysaccharides occurs. During the thermal treatment of wood, dehydration of pentoses to 2-furaldehyde well as oxidation of carbohydrates also occur. New chromophoric groups begin to form in lignin, causing the wood to change color (Fengel and Wegener 1984, Bučko 1995, Hon and Shiraishi 2001, Solár 2004, Sundqvist et al. 2006, Geffert et al. 2019).

The aim of the work is to determine the changes in acidity of beech wood in the technological process of wood color modification with saturated water steam in the temperature range $t=105-135^{\circ} \mathrm{C}$ during 12 hours and to determine the dependence of the total color change of beech wood $\left(\Delta E^{*}\right)$ in CIE $\mathrm{L}^{*} \mathrm{a}^{*} \mathrm{~b}^{*}$ on the $\mathrm{pH}$ value of beech wood obtained by the heat treatment process.

\section{MATERIAL AND METHODS}

\section{Material}

The wood of Fagus sylvatica L. in the form of blanks with dimensions: thickness of $40 \mathrm{~mm}$, width of $90 \mathrm{~mm}$, and length of $750 \mathrm{~mm}$ in 260 pieces was divided into 13 groups of 20 pieces in one group. The initial moisture content of wet beech wood was in the range of values $\mathrm{w}=54.7$ to $58.2 \%$. Group 1 blanks were not thermally treated. The other blanks were divided into 12 groups of 20 pieces each and thermally treated with saturated water steam at $t=105^{\circ} \mathrm{C}, t=125^{\circ} \mathrm{C}$ and $t=135^{\circ} \mathrm{C}$ for $3,6,9$ and $12 \mathrm{~h}$. Thermal treatment of beech wood with saturated water steam was carried out in a pressure autoclave APDZ 240 (Himmasch AD, Haskovo, Bulgaria) installed in the company Sundermann s.r.o., Banská Štiavnica (Slovakia).

\section{Methods}

The conditions of thermal treatment of beech wood with saturated water steam with indicating the sampling time intervals during the thermal treatment $\mathrm{v}$ are shown in Fig. 1.

The thermal process of beech wood color modification was performed in an APDZ 240 autoclave (Himmasch AD, Haskovo, Bulgaria) at a higher saturated water steam pressure than atmospheric pressure. Saturated water steam temperatures in individual color adjustment modes are given in Tab. 1 . 


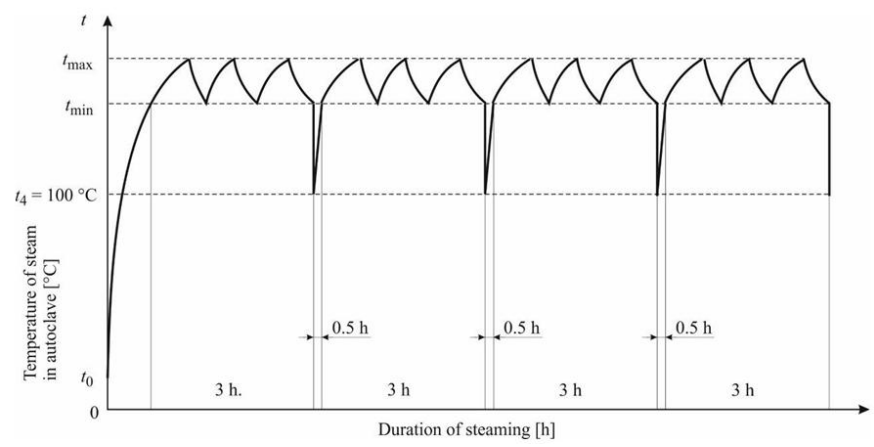

Fig. 1: Mode of color modification of beech wood with saturated water steam.

The temperatures $t_{\max }$ and $t_{\min }$ are the temperature intervals at which saturated water steam is fed into the autoclave to carry out the technological process. Temperature $t_{4}$ is the temperature of the saturated water steam in the autoclave after the water steam pressure in the autoclave has been reduced to atmospheric pressure to allow safe opening of the pressure equipment and sampling after the time thermal treatment $3,6,9$, and $12 \mathrm{~h}$.

Tab. 1: Modes of color modification of beech wood with saturated water steam.

\begin{tabular}{|l|c|c|c|c|c|c|c|}
\hline $\begin{array}{c}\text { Temperature } \\
\text { of saturated } \\
\text { water steam }\end{array}$ & $t_{\min }$ & $t_{\max }$ & $t_{4}$ & \multicolumn{4}{|c|}{ Length of time wood is exposed to color modification } \\
\hline Mode I & 102.5 & 107.5 & 100 & & & \\
\cline { 1 - 4 } Mode II & 122.5 & 127.5 & 100 & $\tau_{1}=3 \mathrm{~h}$ & $\tau_{2}=6\left(+0.5^{\mathrm{a}}\right) \mathrm{h}$ & $\tau_{3}=9\left(+1.0^{\mathrm{a}}\right) \mathrm{h}$ & $\tau_{4}=12\left(+1.5^{\mathrm{a}}\right) \mathrm{h}$ \\
\hline Mode III & 132.5 & 137.5 & 100 & & & & \\
\hline
\end{tabular}

Note: a time for taking out the specimens.

The moisture content and $\mathrm{pH}$ of the wet thermally treated wood were determined by taking samples from the autoclave and cooling the wood to ambient temperature. The moisture content of wet beech wood above the fiber saturation point (BNV) was determined by the gravimetric method according to the standard STN EN 13183-1 (2003).

The $\mathrm{pH}$ of wet beech wood was measured using a $\mathrm{pH}$-meter SI 600 with a Lance FET $+\mathrm{H}$ puncture probe (Sentron, Roden, Netherlands). A hole with a diameter of $12 \mathrm{~mm}$ was created using an accu drill (DeWalt DCD791NT, Germany). Drilling sawdust was pressed into the hole and the LanceFET + H sensor head (Geffert et al. 2019) was inserted into the wet sawdust. After about 60 seconds of stabilization, the $\mathrm{pH}$ value was read on a SI $600 \mathrm{pH}-$ meter (Sentron, Roden, Netherlands).

Color-modified beech wood with saturated water steam treatment technology is used as a material for the production of furniture, flooring or interior tiles in a dry state. For this reason, samples of uncooked and thermally treated beech wood were dried by a gentle drying regime to a final moisture content of $\mathrm{w}=12 \pm 0.5 \%$. Subsequently, the surface of the dry blanks was machined on a FS 200 (BENET Trading, Kvasiny, Slovakia) milling machine.

The color of untreated and thermally treated beech wood in the CIE L* $a^{*} b^{*}$ color space was determined using the Color Reader CR-10 (Konica Minolta, Japan). D65 light source with an 
illuminated area of $8 \mathrm{~mm}$ was used. Color was evaluated based on changes in CIE L* a* b* color space on the coordinate of brightness $\mathrm{L}^{*}$ the red color $\mathrm{a}^{*}$, the yellow color $\mathrm{b}^{*}$ and the total color difference $\Delta E^{*}$. The total color difference value is described by the Eq. 1 .

$$
\Delta \mathrm{E}^{*}=\sqrt{\left(\mathrm{L}_{2}^{*}-\mathrm{L}_{1}^{*}\right)^{2}+\left(\mathrm{a}_{2}^{*}-\mathrm{a}_{1}^{*}\right)^{2}+\left(\mathrm{b}_{2}^{*}-\mathrm{b}_{1}^{*}\right)^{2}}
$$

where: $L_{1}^{*}, a^{*}, b_{1}^{*}$ - values on the color space coordinates of the surface of dried milled thermally untreated beech wood.

$L_{2}^{*}, a_{2}^{*}, b_{2}^{*}$ - values on the color space coordinates of the surface of dried milled thermally treated beech wood.

Using the STATISTICA 12 program (V12.0 SP2, USA), graphical and mathematical dependences of $\mathrm{pH}=\mathrm{f}(t, \tau)$ and $\Delta E^{*}=\mathrm{f}(t, \tau)$ were determined from the measured data in the temperature range: $t=105$ to $135^{\circ} \mathrm{C}$ and time $\tau=3$ to $12 \mathrm{~h}$. The programmatic processing of the measured results partially eliminated the effect of measurement errors due to wood heterogeneity and a direct $\mathrm{pH}$ measurement method (Geffert et al. 2019).

\section{RESULTS AND DISCUSSION}

The light white-gray color with a yellow tinge of dry beech wood of uncooked beech wood was identified in the color space CIE $L^{*} a^{*} b^{*}$ by the coordinates $L^{*}=76.6 \pm 2.3 ; a^{*}=6.9 \pm 1.8$; $b^{*}=19.8 \pm 1.7$. The values given are comparable to the values of color coordinates given for beech wood by the authors (Babiak et al. 2004, Dzurenda 2014, Meints et al. 2017).

In the heat treatment process, the light white-gray color changes to pale pink, red-brown to dark brown shades. The degree of coloring of beech wood by heat treatment with saturated steam is dependent on the temperature and duration of the technological process, as evidenced by Fig. 2 .
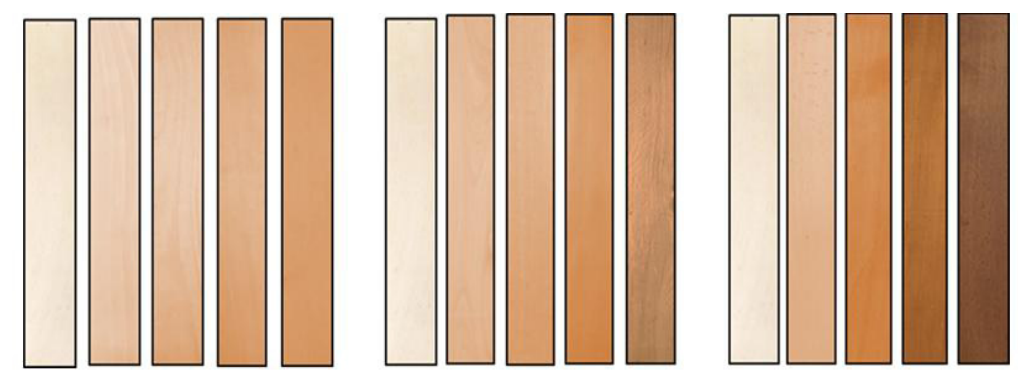

Fig. 2: Changes in the color of beech wood during thermal modification.

Information on changes in the color of beech wood during thermal treatment on the coordinate of brightness $L^{*}$, red color $a^{*}$, yellow color $b^{*}$ and the total color difference $\Delta E^{*}$ is given in Tab. 2. 
Vol. 66 (1): 2021

Tab. 2: Measured values on the coordinates $L^{*}, a^{*}, b^{*}$ in the color space CIE $L^{*} a^{*} b^{*}$, values of the total color difference $\Delta E^{*}$ of beech wood during the process of thermal modification.

\begin{tabular}{|c|c|c|c|c|}
\hline $\begin{array}{c}\text { Temperature of } \\
\text { saturated wate } \\
\text { steam }\end{array}$ & \multicolumn{3}{|c|}{ Time of thermal modification of beech wood color } \\
\cline { 2 - 5 } & $3 \mathrm{~h}$ & $6 \mathrm{~h}$ & $9 \mathrm{~h}$ & $12 \mathrm{~h}$ \\
\hline \multirow{5}{*}{$t_{I}=105 \pm 2.5^{\circ} \mathrm{C}$} & $\mathrm{L}^{*}=75.8 \pm 0.9$ & $\mathrm{~L}^{*}=70.5 \pm 0.8$ & $\mathrm{~L}^{*}=68.9 \pm 1.0$ & $\mathrm{~L}^{*}=67.4 \pm 1.2$ \\
\cline { 2 - 5 } & $\mathrm{a}^{*}=8.5 \pm 0.5$ & $\mathrm{a}^{*}=10.7 \pm 0.4$ & $\mathrm{a}^{*}=10.5 \pm 0.4$ & $\mathrm{a}^{*}=10.3 \pm 0.6$ \\
\cline { 2 - 5 } & $\mathrm{b}^{*}=19.2 \pm 0.4$ & $\mathrm{~b}^{*}=20.2 \pm 0.4$ & $\mathrm{~b}^{*}=20.2 \pm 0.5$ & $\mathrm{~b}^{*}=19.5 \pm 0.5$ \\
\cline { 2 - 5 } & $\Delta E^{*}=1.97$ & $\Delta E^{*}=7.25$ & $\Delta E^{*}=8.64$ & $\Delta E^{*}=9.84$ \\
\hline \multirow{5}{*}{$t_{I I}=125 \pm 2.5^{\circ} \mathrm{C}$} & $\mathrm{L}^{*}=70.5 \pm 0.9$ & $\mathrm{~L}^{*}=64.7 \pm 1.2$ & $\mathrm{~L}^{*}=62.9 \pm 1.0$ & $\mathrm{~L}^{*}=59.7 \pm 0.9$ \\
\cline { 2 - 5 } & $\mathrm{a}^{*}=10.3 \pm 0.4$ & $\mathrm{a}^{*}=11.9 \pm 0.4$ & $\mathrm{a}^{*}=12.5 \pm 0.4$ & $\mathrm{a}^{*}=12.2 \pm 0.4$ \\
\cline { 2 - 5 }$t_{I I I}=135 \pm 2.5^{\circ} \mathrm{C}$ & $\mathrm{b}^{*}=19.8 \pm 0.6$ & $\mathrm{~b}^{*}=17.9 \pm 0.5$ & $\mathrm{~b}^{*}=18.5 \pm 0.4$ & $\mathrm{~b}^{*}=19.8 \pm 0.3$ \\
\cline { 2 - 5 } & $\Delta E^{*}=7.03$ & $\Delta E^{*}=13.01$ & $\Delta E^{*}=14.80$ & $\Delta E^{*}=17.70$ \\
\cline { 2 - 5 } & $\mathrm{L}^{*}=66.6 \pm 0.6$ & $\mathrm{~L}^{*}=60.7 \pm 1.2$ & $\mathrm{~L}^{*}=54.2 \pm 0.8$ & $\mathrm{~L}^{*}=50.4 \pm 1.7$ \\
\cline { 2 - 5 } & $\mathrm{b}^{*}=11.6 \pm 0.2$ & $\mathrm{a}^{*}=12.5 \pm 0.5$ & $\mathrm{a}^{*}=12.5 \pm 0.4$ & $\mathrm{a}^{*}=12.6 \pm 0.4$ \\
\cline { 2 - 5 } & $\Delta E^{*}=11.15$ & $\mathrm{~b}^{*}=19.4 \pm 0.7$ & $\mathrm{~b}^{*}=19.5 \pm 0.6$ & $\mathrm{~b}^{*}=18.8 \pm 0.6$ \\
\hline
\end{tabular}

From the difference of the values on the brightness coordinate $L^{*}$ from the value $L_{0}{ }^{*}=76.8$ of thermally untreated beech wood and the values of $L_{4}{ }^{*}$ of thermally treated beech wood after 12 hours at individual temperatures of thermal treatment it follows that while at temperature $t_{I}=105 \pm 2.5^{\circ} \mathrm{C}$ thermal treatment the brightness decreased by $\Delta L_{4}{ }^{*}=-9.4$, so at thermal treatment with temperature $t_{I I}=125 \pm 2.5^{\circ} \mathrm{C}$ the brightness decreased by $\Delta L_{4}{ }^{*}=-17.1$ and at temperature $t_{I I I}=135 \pm 2.5^{\circ} \mathrm{C}$ the brightness decreased by up to $\Delta L_{4}{ }^{*}=-26.4$. The decrease in the brightness of beech wood with an increase in temperature is not directly proportional. At higher temperatures of the heat treatment process, the decrease in brightness is greater and the darkening of beech wood is more pronounced.

A decrease in values of the coordinate of lightness $L^{*}$ of thermally treated wood is in line with reports of wood darkening in the processes such as wood steaming (Varga and Van der Zee 2008, Tolvaj et al. 2009, 2010), Dzurenda 2014, 2018b,c, Hajdarski and Deliiski 2016, Banski and Dudiak 2019), or drying in warm humid air or high temperature wood drying in a superheated steam environment (Klement and Marko 2009, Dzurenda and Deliiski 2012a,b, Baranski et al. 2017).

Changes in the chromatic coordinate of red color $\mathrm{a}^{*}$ have an increasing tendency. The value of the red color of native wood $a_{0}{ }^{*}=6.9$ increases during 12 hours in a thermal process with the temperature of saturated water steam $t_{I}=105 \pm 2.5^{\circ} \mathrm{C}$ to the value $a_{4}{ }^{*}=10.3$ and at the temperature of water steam $t_{I I I}=135 \pm 2.5^{\circ} \mathrm{C}$ to $a_{4}{ }^{*}=12.6$. The magnitudes of the changes on the red coordinate $a^{*}$ are significantly smaller compared to the changes on the luminance coordinate $L^{*}$. The analysis of the influence of the parameters: temperature and duration of the technological process shows that with increasing temperature the values on the red coordinate $a^{*}$ increase. The largest increase in the values of $\Delta \mathrm{a}^{*}$ manifested by reddening of beech wood is in the first 6 hours of the technological process, a similar statement is given by the authors Banski and Dudiak (2019).

On the coordinate yellow color $b^{*}$, the changes are slight and contradictory, oscillating in a tolerance of \pm 1.6 around the value $b^{*}=18.1$. They point to the formation of less stable compounds with absorption of the electromagnetic radiation spectrum with a yellow wavelength 
of $560 \mathrm{~nm}$. Said compounds react with water or extraction products to form further thermal decomposition products with lower or zero absorption of the yellow wavelength electromagnetic radiation spectrum.

Color changes in beech wood during the thermal treatment, in addition to identification by means of values $L^{*}, a^{*}, b^{*}$ in the color space CIE $L^{*} a^{*} b^{*}$, are aptly characterized by the parameter - the total color difference $\Delta E^{*}$. The dependence of the change of the total color difference $\Delta E^{*}$ on the temperature $\mathrm{t}$ and time $\tau$ of beech wood during heat treatment of wood at saturated water steam temperatures in the range from $t=105$ to $135^{\circ} \mathrm{C}$ and time $\tau=3-12 \mathrm{~h}$., is shown in the form of a $3 \mathrm{D}$ diagram in Fig. 3 and is mathematically described by Eq. 2.

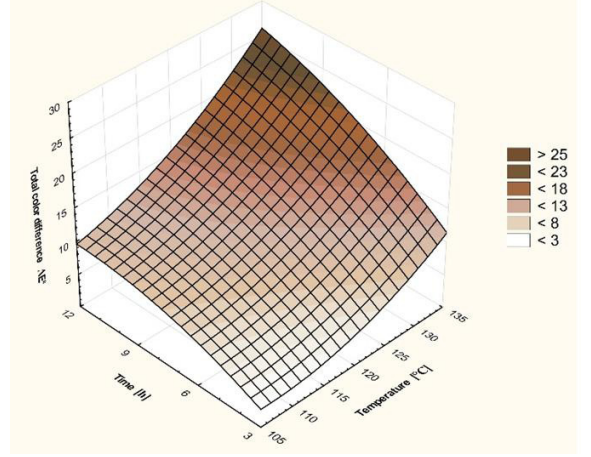

Fig. 3: Correlation of the $\Delta E^{*}$ value of beech wood and the temperature of saturated water steam $t$ and the time $\tau$.

The dependence of the total color difference of beech wood on the temperature of saturated water steam $t$ and time $\tau$ is described by the equation in the form:

$$
\Delta E^{*}=128.919-2.384 \cdot t-1.008 \cdot \tau+0.108 \cdot t^{2}+0.029 \cdot t \cdot \tau-0.085 \cdot \tau^{2}
$$

where: $\mathrm{t}$ - temperature of the saturated water steam ${ }^{\circ} \mathrm{C}$,

$\tau$ - time wood is exposed to color modification in hours.

Under the influence of heat, in the process of thermal treatment of wet beech wood, the processes of hydrolysis of hemicelluloses take place, which are reflected in the change of acidity of beech wood. Measured values of moisture w and acidity $\mathrm{pH}$ of beech wood before the heat treatment process and during heat treatment of beech wood in the technological process measured at time 3, 6, 9 and $12 \mathrm{~h}$. are listed in Tab. 3

Tab. 3: Average values of moisture content and acidity of beech wood in the process of heat treatment of wood.

\begin{tabular}{|c|c|c|c|c|c|c|c|c|c|c|}
\hline \multirow{2}{*}{$\begin{array}{c}\text { Temperature of } \\
\text { saturated water } \\
\text { steam }\end{array}$} & \multicolumn{8}{|c|}{ Time of thermal modification of beech wood } \\
\cline { 2 - 13 } & $w(\%)$ & $p H$ & $w(\%)$ & $p H$ & $w(\%)$ & $p H$ & $w(\%)$ & $p H$ & $w(\%)$ & $p H$ \\
\hline$t_{I}=105 \pm 2.5^{\circ} \mathrm{C}$ & 56.9 & 5.1 & 49.6 & 4.9 & 49.2 & 4.7 & 49.5 & 4.6 & 48.9 & 4.4 \\
\hline$t_{I I}=125 \pm 2.5^{\circ} \mathrm{C}$ & 55.8 & 5.2 & 44.3 & 4.3 & 44.9 & 4.0 & 45.2 & 3.9 & 44.7 & 3.8 \\
\hline$t_{I I I}=135 \pm 2.5^{\circ} \mathrm{C}$ & 56.5 & 5.1 & 46.5 & 3.8 & 45.8 & 3.7 & 46.0 & 3.5 & 44.3 & 3.4 \\
\hline
\end{tabular}


The moisture values of the thermally treated beech wood after cooling to ambient temperature were lower than the moisture of the wood before the thermal treatment. Reduction of beech wood moisture content by $\Delta w=6.9$ to $12.6 \%$ is caused by evaporation of water from wood to saturated water steam in autoclave during cooling to temperature $t=100^{\circ} \mathrm{C}$ before sampling from autoclave and vaporization of water from wood to atmosphere during cooling of wood to ambient air temperature. The source of heat for evaporation and vaporization of water from wood is the heat accumulated during the heating of the wood to the required technological temperature (Dzurenda and Deliiski 2000, Dzurenda 2018d).

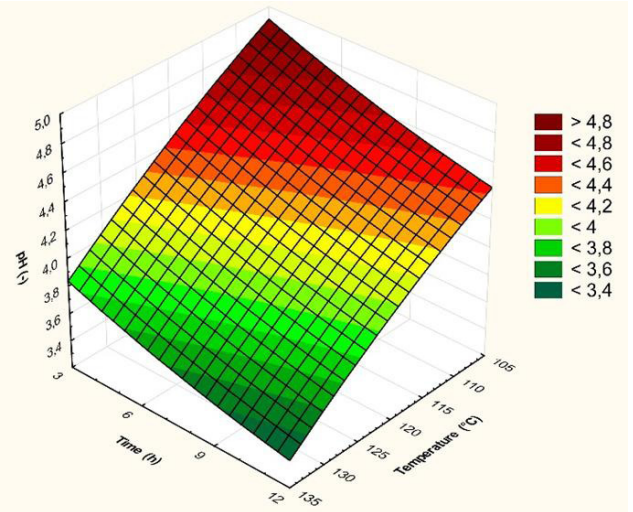

Fig. 4: Correlation of the $\mathrm{pH}$ value of wet beech wood and the temperature of saturated water steam tand the time $\tau$.

Changes in the acidity of beech wood in the heat treatment process are a confirmation of the known knowledge about the decrease in the $\mathrm{pH}$ of wet wood (Bučko 1995, Sundqvist et al. 2006, Samešova et al. 2018, Geffert et al. 2019). From experimentally measured $\mathrm{pH}$ values of beech wood during heat treatment of wood with saturated steam in the range of temperatures from $t=105$ to $135^{\circ} \mathrm{C}$ and time $\tau=3-12 \mathrm{~h}$, a graphical dependence of the change in acidity on temperature and time was determined in the form of a 3D diagram (Fig. 4).

Changes in the acidity values of wet beech wood at the temperature of saturated water steam in the range of values $t=105-135^{\circ} \mathrm{C}$ and time $\tau=3-12$ hours are given by a mathematical equation in the form:

$$
p H=5.0217+0.0236 \cdot t-0.1021 \cdot \tau-0.00022 \cdot t^{2}+0.0002 \cdot t \cdot \tau+0.0019 \cdot \tau^{2}
$$

where: $t$ - temperature of the saturated water steam ${ }^{\circ} \mathrm{C}$,

$\tau$ - time wood is exposed to color modification in hours.

The course of changes in the total color difference $\Delta E^{*}$ on the acidity of wet beech wood in the process of thermal treatment in the temperature range $t=105-135^{\circ} \mathrm{C}$ and the time of the technological process $\tau=3-12$ h. is shown in Fig. 5 . 


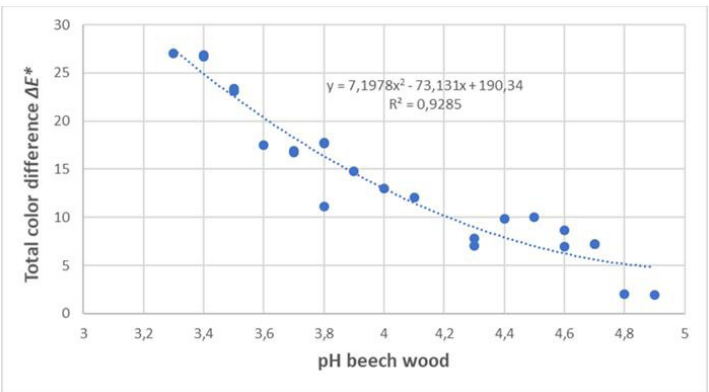

Fig. 5: Dependence on the total color difference of beech wood $\Delta E^{*}$ on the acidity value of beech wood $p H$ in the heat treatment process.

The dependence of the total color difference of beech wood on the value of acidity is mathematically described by the function:

$$
\Delta E^{*}=7.1978 \cdot(p H)^{2}-73.131 \cdot(p H)+190.34
$$

where: $p H$ - acidity value of wet beech wood.

A similar dependence of the total color difference of wood on the $p H$ value of wet thermally treated beech wood is presented in the work Dzurenda et al. (2020).

It can be seen from the resulting dependence that the color of the heat-treated beech wood acquires darker shades due to the temperature of the saturated water steam and the modification time. The $p H$ values of wet thermally treated wood, depending on the temperature of the saturated steam and the time of treatment decrease, i.e. they have a more acidic $p H$, which can be clearly seen in the given dependence the darker the shade the lower (more acidic) $p H$. The dependence of the total color difference $\Delta E^{*}$ on the change in the acidity of beech wood in the thermal process is a suitable tool for evaluating the achieved color change based on the $p H$ of beech wood in the technological process.

\section{CONCLUSIONS}

(1) The paper presents the results of color change and acidity of Fagus sylvatica L. wood in the process of heat treatment of wood with saturated water steam at temperatures: $t_{I}=105 \pm 2.5^{\circ} \mathrm{C}, t_{I I}=125 \pm 2.5^{\circ} \mathrm{C}$ and $t_{I I I}=135 \pm 2.5^{\circ} \mathrm{C}$ for $\tau=12$ hours.

(2) The color of beech wood changes from a light white-gray color with a yellow to pale pink, red-brown to a brown-red color in the heat treatment process. The magnitude of color changes is mathematically described by the equation $\Delta E^{*}=128.919-2.384 \cdot t-1.008 \cdot \tau+$ $0.108 \cdot t^{2}+0.029 \cdot t \cdot \tau-0.085 \cdot \tau^{2}$.

(3) The rate of change of acidity from $\mathrm{pH}=5.1$ to $\mathrm{pH}=3.4$ in the process of thermal modification of beech wood color at temperature $t$ time $\tau$ is described by the equation: $p H=5.0217+0.0236 \cdot t-0.1021 \cdot \tau-0.00022 \cdot t^{2}+0.0002 \cdot t \cdot \tau+0.0019 \cdot \tau^{2}$.

(4) The dependence of the total color change $\Delta E^{*}$ of beech wood on the acidity of thermally treated wood in the range of values $\mathrm{pH}=4.9-3.4$ is described by the equation: $\Delta E^{*}=7.1978 \cdot(p H)^{2}-73.131 \cdot(p H)+190.34$. 


\section{ACKNOWLEDGMENTS}

This experimental research was prepared within the grant project: APVV-17-0456 "Termická modifikácia dreva sýtou vodnou parou za účelom cielenej a stabilnej zmeny farby drevnej hmoty" as the result of work of authors and the considerable assistance of the APVV agency.

\section{REFERENCES}

1. Babiak, M., Kubovský, I., Mamoňová, M., 2004: Farebný priestor vybraných domácich drevín (Color space of selected domestic trees). In: Interaction of wood with various forms of energy, $3^{\text {rd }}$ International Scientific Symposium, Zvolen, Pp. 113-117.

2. Banski, A., Dudiak, M., 2019: Dependence of color on the time and temperature of saturated water steam in the process of thermal modification of beech wood. In: AIP $38^{\text {th }}$ Meeting of Departments of Fluid Mechanics and Thermodynamics, 2118: 030003.

3. Barański, J., Klement, I., Vilkovská, T., Konôpka, A., 2017: High temperature drying process of beech wood (Fagus sylvatica L.) with different zones of sapwood and red false heartwood. BioResources 12(1): 1861-1870.

4. Barcik, Š., Gašparík, M., Razumov, E.Y., 2015: Effect of thermal modification on the colour changes of oak wood. Wood Research 60(3): 385-396.

5. Blažej, A., Sutý, L., Košík, M., Krkoška, P., Golis, E., 1975: Chémia dreva (Chemistry of wood). ALFA, Bratislava, 221 pp.

6. Bučko, J., 1995: Hydrolýzne procesy (Hydrolysis processes). Technical University in Zvolen, Zvolen, 116 pp.

7. Čudinov, B.S., Stepanov, V.L., 1968: Phasenzusammensetzung der Wasser in gefrorenem Holz. In: Holztechnologie 9(1): 14-18.

8. Dzurenda, L., Deliiski, N., 2000: Analysis of moisture content changes in beech wood in the steaming process with saturated water steam. Wood Research 45(4): 1-8.

9. Dzurenda, L., Orlowski K., 2011: The effect of thermal modification of ash wood on granularity and homogeneity of sawdust in the sawing process on a sash gang saw PRW 15-M in view of its technological usefulness. Drewno 54(186): 27-37.

10. Dzurenda, L., Deliiski N., 2012a: Convective drying of beech lumber without color changes of wood. Drvna industrija 63(2): 95-103.

11. Dzurenda, L., Deliiski N., 2012b: Sušenie bukového reziva v komorových sušiarňach režimami zachovávajúcimi pôvodnú farbu dreva (Drying of beech timber in chamber drying kilns by regimes preserving the original colour of wood). Acta facultatis xylologiae Zvolen 54(1): 33-42.

12. Dzurenda, L., 2013: Modification of wood colour of Fagus sylvatica L. to a brown-pink shade caused by thermal treatment. Wood research 58(3): 475-482.

13. Dzurenda, L., 2014: Colouring of beech wood during thermal treatment using saturated water steams. Acta facultatis xylologiae Zvolen 56(1): 13 - 22.

14. Dzurenda, L., 2018a: The shades of color of Quercus robur L. wood obtained through the processes of thermal treatment with saturated water vapor. BioResouces 13(1): 1525-1533.

15. Dzurenda, L., 2018b: Hues of Acer platanoides L. resulting from processes of thermal treatment with saturated steam. Drewno 61(202): 165-176.

16. Dzurenda, L., 2018c: Colour modification of Robinia pseudoacacia L. during the processes of heat treatment with saturated water steam. Acta Facultatis Xylologiae Zvolen 60(1): 61-70. 
17. Dzurenda, L., 2018d: The effect of moisture content of Black locust wood on the heating in the saturated water steam during the process of colour modification. In: MATEC Web of Conferences 168(181): 06004.

18. Dzurenda, L., Geffert, A., Geffertová, J., Dudiak, M., 2020: Evaluation of the process thermal treatment of maple wood saturated water steam in terms of change of $\mathrm{pH}$ and color of wood. BioResources 15(2): 2550-2559.

19. Fengel, D., Wegener, G., 1984: Wood: chemistry, ultrastructure, reactions. Walter de Gruyter: Berlin, 613 pp.

20. Hadjiski, M., Deliiski, N., 2016: Advanced control of the wood thermal treatment processing. In: Cybernetics and Information Technologies. Bulgarian Academy of Sciences 16(2): 176-197.

21. Geffert, A., Geffertová, J., Dudiak, M., 2019: Direct method of measuring the $\mathrm{pH}$ value of wood. Forests 10(10): 852.

22. Klement, I., Marko, P., 2009: Colour changes of beech wood (Fagus sylvatica L.) during high temperature drying process. Wood Research 54(3): 45-54.

23. Kollmann, F., Côte, W.A., 1968: Principles of wood sciences and technology. Vol. 1. Solid Wood. Springer Verlag, Berlin, Germany, 592 pp.

24. Meints, T., Teischinger, A., Stingl, R., Hassmann, C., 2017: Wood colour of central European wood species: CIELAB characterisation and colour intensification. European Journal of Wood and Wood Products 75: 499-509.

25. Molnar, S., Tolvaj, L., 2002: Colour homogenisation of different wood species by steaming. In: Interaction of wood with various forms of energy. Pp 119-122, Technical University in Zvolen.

26. Pňakovič, L., Dzurenda, L., 2015: Combustion characteristics of fallen fall leaves from ornamental trees in city and forest parks. BioResources 10(3): 5563-5572.

27. Samešová, D., Dzurenda, L., Jurkovič, P., 2018: Kontaminácia kondenzátu produktmi hydrolýzy a extrakcie z tepelného spracovania bukového a javorového dreva pri modifikácii farby dreva (Contamination of water by hydrolysis products and extraction from the thermal treatment of beech and maple timber during modification the color of wood). Chip and Chipless Woodworking Processes 11(1): 277-282.

28. Sanderman, W., Rothkamm, M., 1959: The determination of $\mathrm{pH}$ values of woods and their practical importance. Holz Roh- Werkstoff 17: 433-441.

29. Sikora, A., Kačík, F., Gaff, M., Vondrova, V., Bubeníkova, T., Kubovský, I., 2018: Impact of thermal modification on color and chemical changes of spruce and oak wood. Journal of Wood Science 64: 406-416.

30. Sundqvist, B., Karlsson, O., Westremark, U., 2006: Determination of formic-acid and acid concentrations formed during hydrothermal treatment of birch wood and its relation to color, strength and hardness. Wood Science and Technology 40(7): 549-561.

31. Sergovskij, P.S., Rasev, A.I., 1987: Gidrozermicheskaya obrobotka i konservironaniye drevesiny (Hydrothermal treatment and conservation of wood). Lesnaja promyslennost Moscow, Russia, 360 pp.

32. Solár, R., 2004: Chémia dreva (Wood chemistry). Technical University in Zvolen, Zvolen, Slovakia, $101 \mathrm{pp}$.

33. STN EN 13183-1, 2003: Moisture content of a piece of sawn timber. Part1: Determination by oven dry method.

34. Tolvaj, L., Nemeth, R., Varga, D., Molnar, S., 2009: Colour homogenisation of beech wood by steam treatment. Drewno 52(181): 5-17. 
35. Tolvaj, L., Molnar, S., Nemeth, R., Varga, D., 2010: Color modification of Black locust depending on the steaming parameters. Wood Research 55(2): 81-88.

36. Trebula, P., 1986: Sušenie a hydrotermická úprava dreva (Drying and hydrothermal treatment of wood). Zvolen: TU Zvolen, $255 \mathrm{pp}$.

37. Varga, D., Van der Zee, M.E., 2008: Influence of steaming on selected wood properties of four hardwood species. Holz als Roh-und Werkstoff 66(1): 11-18.

38. Zevenhoven, M., 2001: Ash-forming matter in biomass fuels. Åbo Akademi University, Turku, Finland, 120 pp.

\author{
Ladislav Dzurenda*, Michal Dudiak \\ Technical University in Zvolen \\ Faculty of Wood Sciences and Technology \\ T.G. MASARyka 24 \\ 960or Zvolen \\ Slovakia \\ *Corresponding author: dzurenda@tuzvo.sk
}


